\title{
FOLIAR APPLICATION OF DI-AMMONIUM PHOSPHATE AND TRIPLE SUPER PHOSPHATE ON LENTIL AT DROUGHT PRONE AREA OF BANGLADESH
}

\author{
MOHAMMED BELAL HOSSAIN* AND SNIGDHA ROY ${ }^{2}$, A.B.M. SHAFIUL ALAM ${ }^{3}$ \\ Soil Science Division, Bangladesh Institute of Nuclear Agriculture (BINA), Bangladesh Agricultural \\ University campus, Mymensingh 2202, Bangladesh
}

\begin{abstract}
A field experiment was conducted to investigate the effect of foliar application of DAP and TSP on yield and yield attributing characters of lentil. Foliar application of DAP and TSP was performed at flowering and pod formation stages of lentil. Results revealed that maximum fresh weight of plant, nodule number and dry weight of nodule were recorded in $\mathrm{F}_{2}$ treatment at $50 \%$ flowering stage of lentil. $F_{1}$ treatment produced higher branch plant ${ }^{-1}(2.66)$, pod plant ${ }^{-1}(106.47)$ and seed yield $(0.72 \mathrm{t}$ $\mathrm{ha}^{-1}$ ) of lentil. DAP increased $6 \%$ higher grain yield than no foliar application of fertilizer. It may be suggested that foliar application of DAP is a better technology for increasing lentil production in drought prone area of Bangladesh.
\end{abstract}

Key words: Drought area, Foliar spray, DAP, TSP, Lentil, Yield

Maintaining food and nutritional security for the increasing population of the world is a great challenge for us (Lobell and Burke 2010). Besides emphasizing main crops and vegetables, various pulses play an important role to satisfy the growing human food demands. Among the food crops, pulses are important source of protein and it provides nutritional security. Generally lentil is grown as a post-rainy season crop in the rain-fed areas of Bangladesh. Rain fed reduces crop yield due to lack of nutrients movement by water from soil to plants. Under rain fed condition, drought is a serious problem at flowering and pod formation stages of crops because insufficient soil water can hamper pollination and sink of different compounds to grain from other parts of plant. In many places of developing countries like Bangladesh, water stress is the major constraint to agricultural production that impairs the quality, growth and production of crops (Ahmad et al. 2015). Under this circumstance foliar application of fertilizer would be more efficient and economical than the soil application (Rajesh and Paulpandi 2013). On the other hand, foliar application is regarded as a preferred solution when quick supply of nutrients is hindered or the soil conditions are not conducive for the absorption of nutrients (Salisbury and Ross 1985). Keeping the above points in view the foliar spraying of DAP and TSP was evaluated for their effect on lentil production in drought area of Bangladesh.

\footnotetext{
* Corresponding author: <belalbina@ gmail.com>.

${ }^{2}$ Plant Breeding Division, Bangladesh Institute of Nuclear Agriculture (BINA), Bangladesh Agricultural University campus, Mymensingh 2202, Bangladesh.

${ }^{3}$ Adaptive Research and Extension Division, Bangladesh Institute of Nuclear Agriculture (BINA), Bangladesh. Agricultural University campus, Mymensingh 2202, Bangladesh.
} 
Field experiment was conducted during rabi season of 2017-18 at Bangladesh Institute of Nuclear Agriculture (BINA) Substation, Chapai Nawabganj, Bangladesh. The experimental field was well prepared and laid out in a randomized block design with three replications. Treatment combinations were $\mathrm{F}_{0}=$ control (no foliar application of DAP and TSP), $\mathrm{F}_{1}=$ foliar application of DAP and $\mathrm{F}_{2}=$ foliar application of TSP. The soil was a silty loam having $\mathrm{pH} 7.20$, organic carbon $1.20 \%$, total $\mathrm{N} 0.105 \%$, available P 3.75ppm, available S $20.17 \mathrm{ppm}$ and exchangeable K $0.105 \%$ meq. Binamasur 5 was used as the test crop. The plot size was $(4 \mathrm{~m} \times$ $3 \mathrm{~m}) 12 \mathrm{~m}^{2}$. The fertilizer applied was $20,40,40$ $\mathrm{kg} \mathrm{N}, \mathrm{P}_{2} \mathrm{O}_{5}, \mathrm{~K}_{2} \mathrm{O}$ per ha as basal in the form of were randomly selected at harvest stage for collecting data on plant height, number of branch plant ${ }^{-1}$, number of pods per plant $^{-1}$ and number of effective pod plant ${ }^{-1}$. Collected data were analyzed statistically following the one way ANOVA technique with the help of MSTAT-C software (Gomez and Gomez 1984). The mean differences among the treatments were adjusted by DMRT.

Results showed that foliar application of DAP and TSP did not show any significant effect on plant height, fresh weight of plant and dry weight of nodule at $50 \%$ flowering stage of lentil (Table 1). Maximum plant height $(28.87 \mathrm{~cm})$ was found in $F_{1}$ treatment. The highest fresh

Table 1. Effects of foliar application of fertilizers on yield attributing characters of lentil

\begin{tabular}{c|c|c|c|c|c|c|c|c|c}
\hline Treatment & \multicolumn{3}{|c|}{$50 \%$ flowering stage } & \multicolumn{5}{c}{ Harvest stage } \\
\hline & $\begin{array}{c}\text { Plant } \\
\text { height } \\
(\mathrm{cm})\end{array}$ & $\begin{array}{c}\text { Fresh } \\
\text { wt./pla } \\
\text { nt (gm) }\end{array}$ & $\begin{array}{c}\text { Nodule } \\
\text { no./plant }\end{array}$ & $\begin{array}{c}\text { Dry wt. of } \\
\text { nodule } \\
\text { /plant }\end{array}$ & $\begin{array}{c}\text { Plant } \\
\text { height } \\
(\mathrm{cm})\end{array}$ & $\begin{array}{c}\text { Branch/ } \\
\text { plant } \\
\text { (no.) }\end{array}$ & $\begin{array}{c}\text { Pod/pla } \\
\text { nt (no.) }\end{array}$ & $\begin{array}{c}\text { Effectiv } \\
\text { e } \\
\text { pod/pla } \\
\text { nt (no.) }\end{array}$ & $\begin{array}{c}\text { Hay } \\
\text { yield (t } \\
\left.\text { ha }^{-1}\right)\end{array}$ \\
\hline & & & & & & & & & \\
$\mathrm{F}_{0}$ & 27.73 & 6.47 & $2.33 \mathrm{~b}$ & 12.33 & $30.92 \mathrm{a}$ & 2.62 & 102.93 & 86.73 & 1.62 \\
$\mathrm{~F}_{1}$ & 28.87 & 7.73 & $2.00 \mathrm{~b}$ & 10.33 & $27.80 \mathrm{~b}$ & 2.66 & 106.47 & 96.27 & 1.60 \\
$\mathrm{~F}_{2}$ & 27.73 & 7.80 & $4.50 \mathrm{a}$ & 13.00 & $28.00 \mathrm{~b}$ & 2.63 & 103.13 & 98.73 & 1.60 \\
$\mathrm{CV}(\%)$ & 6.42 & 21.07 & 17.90 & 30.65 & 1.73 & 6.68 & 6.60 & 6.61 & 10.23 \\
Sig. level & $N S$ & $N S$ & $*$ & $N S$ & $*$ & $N S$ & $N S$ & $N S$ & $N S$ \\
\hline
\end{tabular}

In a column, figures having similar letters do not differ significantly as per DMRT. *Significant at $1 \%$ level, NS-Non-significant.

urea, single super phosphate and muriate of potash. All the fertilizers were applied before sowing of lentil seed. Three per cent (3\%) DAP (di-ammonium phosphate) and 2\% TSP (triple super phosphate) were applied at flowering and pod formation stages of lentil. Hand weeding was done twice at 20 and 40 days after sowing. Normal cultural practices were adopted to raise a good crop. Five plant samples from each plot weight $(7.80 \mathrm{~g})$, nodule number (4.50) and dry weight of nodule $(13 \mathrm{~g})$ per plant were recorded in $\mathrm{F}_{2}$ treatment at $50 \%$ flowering stage of lentil.

At harvest stage, the highest plant height $(30.92 \mathrm{~cm})$ was found in control $\left(\mathrm{F}_{0}\right)$ treatment but the important yield contributing characters of lentil like number branches plant ${ }^{-1}$ and number of pods plant ${ }^{-1}$ were higher in $F_{1}$ and $F_{2}$ 
treatments. Maximum number of branches plant ${ }^{-1}$ was observed in $F_{1}$ treatment. Ram and Punia (2007) have also recorded higher number of branches plant ${ }^{-1}$ with foliar application of urea in lentil. The maximum number of pods per plant was observed when DAP was supplied to plants through foliage while minimum number of pods per plant was noted in the plants with no foliage fertilizer application. Both the treatments $\left(\mathrm{F}_{1}\right.$ and $\mathrm{F}_{2}$ ) significantly increased number of pods plant ${ }^{1}$ over the control. The maximum number of effective pod per plant was also recorded with treatment $F_{1}$ and $F_{2}$ which were significantly higher over the control. This might be due to quick and more availability of nitrogen and phosphorus from DAP to the leaves for maximum photosynthesis process. Foliar application of DAP produced more grains per pod in green gram (Raman 2006, Nigmananda and Elamathi 2007). Ram and Punia (2007) reported similar results of foliar application of urea for increasing the number of grains $\operatorname{pod}^{-1}$ in lentil. Results indicated that foliar application of DAP and TSP significantly increased grain yield of lentil (Fig. 1). Maximum grain yield was initiation stages. Good interaction and compatibility between nitrogen and phosphorus in DAP helped to better utilization and intake of nitrogen and phosphorus to the crop plant, which ultimately resulted in higher grain yield than other treatments. Foliar application of DAP increased $6 \%$ grain yield over control treatment. Increase in yield and yield attributes might be due to fulfillment of the demand of the crop by higher assimilation and translocation of photosynthates from source to sink through adequate supply of nutrients by foliar application of fertilizers (Kuttimani and Velayutham 2011) The highest hay yield was obtained from $F_{0}$ treatment. Same hay yield $\left(1.60 \mathrm{t} \mathrm{ha}^{-1}\right)$ was found in $F_{1}$ and $F_{2}$ treatments. From these results it may be suggested that foliar application of DAP can increase grain yield of lentil at drought prone area of Bangladesh. Plant height $\left(\mathrm{r}^{2}=0.798\right)$, branch number $(\mathrm{r}+=0.923)$, pod number $\left(r^{2}=0.792\right)$ and effective pod number $\left(r^{2}=0.566\right) \quad$ showed significant positive correlation with grain yield of lentil. On the other hand, hay yield $\left(r^{2}=0.750\right)$ showed significant negative correlation with grain yield

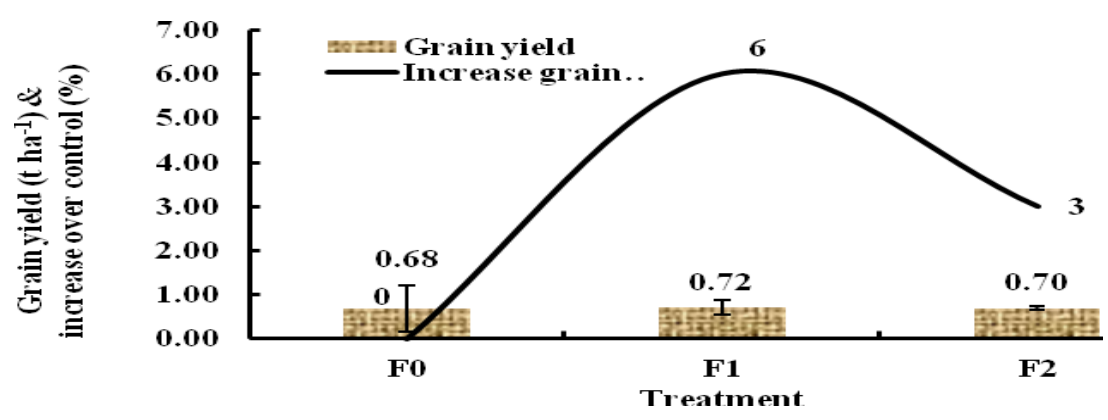

Fig. 1. Effects of foliar nutrition on grain yield of lentil

found in $\mathrm{F}_{1}$ treatment.

when it was applied once at flowering stage and other at pod initiation stage. TSP fertilizer has also responded significantly better when it was applied at flowering stage and other at pod of lentil.

From the regression studies it was clear that foliar application of TSP and DAP recorded significant effect on growth, pod formation and pod filling of lentil. (Table 2) 
Table 2. Correlation regression between yield and yield contributing characters of lentil

\begin{tabular}{lcc}
\hline Parameters & Regression line & $\begin{array}{c}\text { Correlation co-efficient } \\
\left(\mathbf{R}^{2} \text { value }\right)\end{array}$ \\
\hline Plant height Vs grain yield & $\mathrm{y}=-0.0102 \mathrm{x}+0.9957$ & $0.798^{* *}$ \\
Branch number Vs grain yield & $\mathrm{y}=0.9231 \mathrm{x}-1.7338$ & $0.923^{* *}$ \\
Pod number Vs grain yield & $\mathrm{y}=0.009 \mathrm{x}-0.2326$ & $0.792^{* *}$ \\
Effective pod Vs grain yield & $\mathrm{y}=0.0024 \mathrm{x}-0.477$ & $0.566^{*}$ \\
Hay yield Vs grain yield & $\mathrm{y}=-1.5 \mathrm{x}+3.11$ & $0.750^{* *}$ \\
\hline
\end{tabular}

Foliar spray of DAP (3\%) increased $6 \%$ grain yield of lentil over control treatment. In drought prone areas, foliar spray of DAP $(3 \%)$ treatment at flowering and pod formation stages was the most effective in terms of improving growth and yield of lentil in water stress environment where nutrient uptake is greatly limited.

\section{REFERENCES}

Ahmad, Z., E. A. Waraich, R. Ahmad, M. A. Iqbal and M. I. Awan. 2015. Studies on screening of maize (Zea mays L) hybrids under drought stress conditions. J. Advan. Bot. Zoology 2: 1-5.

Gomez, K. A. and A. A. Gomez. 1984. Statistical procedures for agricultural research, 2nd ed., John Wiley and Sons, Singapore. p. 98.

Kuttimani, R. And A. Velayutham. 2011. Foliar application of nutrients and growth regulators on yield and economics of green gram. Madras Agric. J. 98(4): 141- 143.

Lobell, D. B. and M. B. Burke. 2010. On the use of statistical models to predict crop yield responses to climate change. Agric. Meteorology 150: 1443-1452.
Nigamananda, B. and S. Elamathi. 2007. Studies on the time of nitrogen, application foliar spray of DAP and growth regulator on yield attributes, yield and economics of green gram (Vigna radiata L). Int. J. Agril. Sci. 3: 168-169.

Rajesh, N. and V. K. Paulpandi. 2013. Review of foliar nutrition in red gram enhancing the growth and yield characters. Am. Int. J. Res. Formal, Appl. Natural Sci. 13-142: 9-14.

Ram, B and S. S. Punia. 2007. Effect of seed priming and urea spray on growth yield attributes and yield of lentil (Lens culinaris Medik). Abst. of papers, National Symposium of NLS held at IIPR, Kanpur on Nov. 3-5: 80.

Raman, R. and K. Venkataramana. 2006. Effect of foliar nutrition on NPK uptake, yield attributes and yield of green gram [(Vigna radiata L) Wilczek]. Crop Res. Hisar 32: 21-23.

Salisbury, F. B. and M. B. Kamath. 1985. Plant Physiology, 3rd edition Wadsworth, Belmont, CA. p. 540.

(Received revised manuscript on 28 November 2018) 